\title{
The effect of carbamazepine monotherapy on full blood count in epileptic patients
}

\author{
Deena K.Alsamman*, Faris A. Ahmed**, Harith K M Al-kazzaz** \\ *Department of Pharmacology, Collage of Pharmacy, ${ }^{* *}$ Department of Physiology, Ninevah College of Medicine, \\ University of Mosul
}

$\frac{\text { Received } \quad \text { Accepted }}{\text { Y.T.Y.1. }}$

\begin{abstract}
Objectives: To assess the effect of carbamazepine on full blood count in epileptic patients.

Patients and Methods: This study was done in the Outpatient department of IbnSina Hospital in Mosul, during the period from October $r \ldots \leqslant$ to September $r_{\cdots}$. Epileptic patients under oral carbamazepine therapy $\left.\left(\gamma_{\cdots-}\right) r_{\cdots} \mathrm{mg} / \mathrm{day}\right)$ were included in this study. The patients were $\leqslant \leqslant$ males and $r \tau$ females. The duration of treatment was between $1-r \cdot$ years. The control subjects included $\leqslant 1$ males and ro females. They were apparently healthy subjects. Blood samples were taken from patients and controls and analyzed for full blood count including hemoglobin $(\mathrm{Hb})$, mean corpuscular volume $(\mathrm{MCV})$, mean corpuscular $\mathrm{Hb}$ concentration (MCHC), mean corpuscular $\mathrm{Hb}(\mathrm{MCH})$, red cell distribution width (RDW), red blood cell count (RBC count), hematocrit \% (PCV), white blood cell count (WBC count) and platelets. Results: In both male and female patients, $\mathrm{Hb}$ was significantly lower than that in the control group, respectively. The other measurements of full blood count, there were no significant differences compared with the control group in both male and female, respectively.
\end{abstract}

Conclusion: Chronic use of carbamazepine in epileptic patients is relatively safe on full blood count. Periodical examination of full blood count is necessary for epileptic patients under carbamazepine therapy.

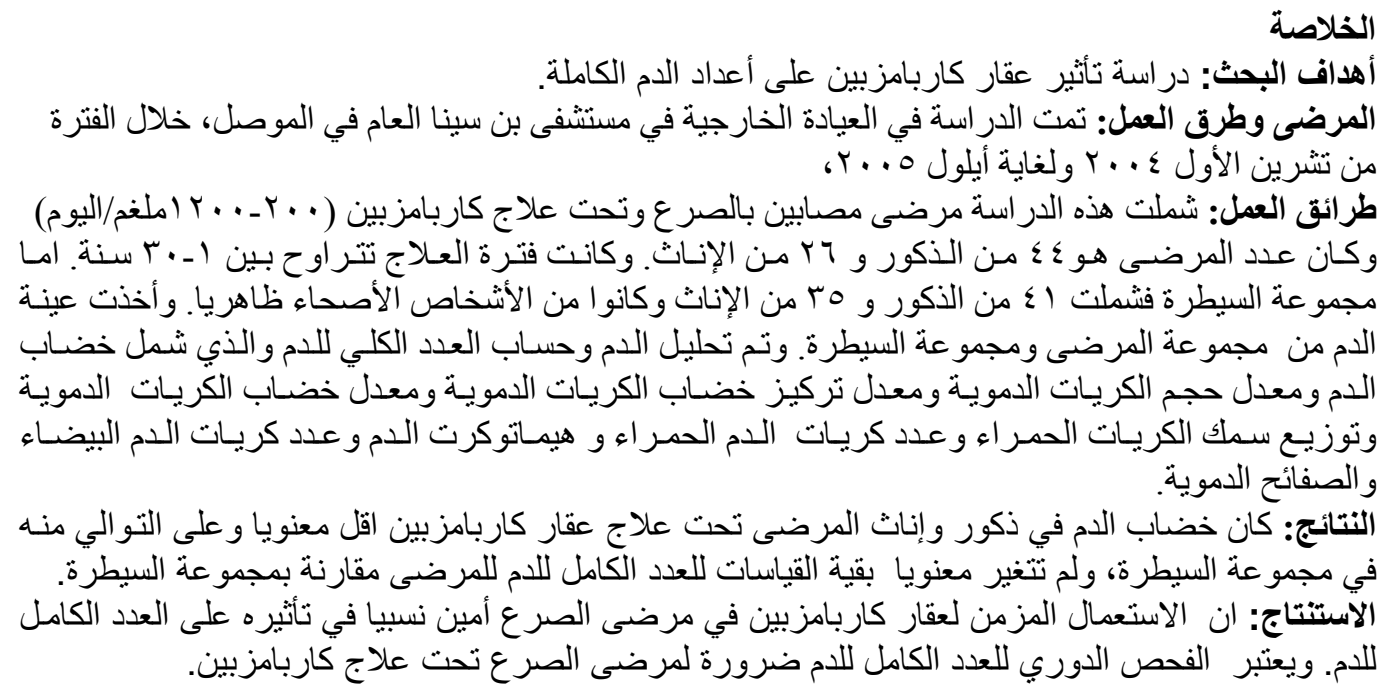


7 he wide spread and chronic use of carbamazepine in multiple neurological disorders makes a drug whose most frequent side effects are well known and controlled.' Most of the side effects associated with carbamazepine are mild, transient and reversible with an adjustment of dosage. ${ }^{r}$ However, serious blood disorder as thrombocytopenia ${ }^{\xi, 0}$ and aplastic anemia ${ }^{\uparrow,}, \wedge$ are rare in patients with carbamazepine therapy.

In Iraq, carbamazepine therapy is not pharmacologically monitored. Therefore, this study was conducted to evaluate the effect of chronic use of carbamazepine on full blood count in epileptic patients.

\section{Patients and methods}

The study was carried out in the Neurology Outpatient Department in Ibn-Sina Hospital under supervision of neurologist, during the period from October $r \ldots \leqslant$ to September $r \ldots o$.

Seventy six epileptic patients were included in this study. The patients were received carbamazepine monotherapy for at least one year. Those patients comprised 0 . males, their ages ranged between $1 \tau_{-} \leqslant V$ years (mean \pm SD: $r \cdot .0 \pm 9 . \varepsilon$ years) and $r \tau$ females, their ages ranged between $1 \tau_{-} \leqslant 0$ years ( $r, r_{ \pm} q^{\wedge} \wedge$ years). The duration of treatment was between 1$r \cdot$ years $\left(\wedge .9 r_{ \pm} \wedge.\right)$ years $)$, with daily dose between $r \ldots-l, \ldots$ mg. Any other diseases or medications were excluded.

The control group comprised $V\urcorner$ apparently healthy subjects, none of them were taken any medications. They were $\leqslant$ males their ages ranged between 1 7.0. years $(r) . \wedge \pm 9 . r)$ and ro females their ages ranged between $1 V_{-} 0 \cdot$ years $(Y 9.0 \pm 9.0$ years).

Blood samples ( $r \mathrm{ml})$ were taken from both groups and transferred to EDTA tubes. The haematological parameters were measured by haematology auto analyzer (Bergmann Coulter Counter, Germany) at IbnSina haematology laboratory.

Data are presented as mean $\pm \mathrm{SD}$. Unpaired t-test was used to compare between patients and control parameters.

\section{Results}

RBCs indices including, mean corpuscular volume (MCV), mean corpuscular $\mathrm{Hb}(\mathrm{MCH})$, mean corpuscular $\mathrm{Hb}$ concentration (MCHV), red cell distribution width (RDW), red blood cell count (RBC count), hematocrit \% (PCV), in addition to white blood cell count (WBC) were not significantly different in carbamazepine patients as compared to control group for both males and females. Only $\mathrm{Hb}$ decreased significantly in males and females patients compared with the control group, respectively (Table 1). Platelet count showed a decline but not significant in both male and female patients compared with controls

\section{Discussion}

In this study, there is no significant decline in $\mathrm{RBC}$ indices (except for $\mathrm{Hb}$ level) in both males and females patients compared with the control group. This result is in agreement with previous studies. ${ }^{9}, \cdot \mathrm{Hb}$ level decreased significantly for both male and females in patients group as compared to the control group, this result is in agreement with other result." Tagawa" observed that low $\mathrm{Hb}$ levels of the patients had been raised to the normal levels within 'weeks after discontinuation of carbamazepine therapy. Shah et al. ${ }^{1 r}$ observed that low $\mathrm{Hb}$ level might be result of decreased total serum iron concentration by the effect of carbamazepine as enzyme inducer that led to depletion of iron stores. 
Table '. Complete blood picture of epileptic patients treated with carbamazepine and controls.

\begin{tabular}{|c|c|c|c|c|}
\hline \multirow{2}{*}{$\begin{array}{l}\text { Hematological } \\
\text { parameters }\end{array}$} & \multicolumn{2}{|c|}{ Males } & \multicolumn{2}{|c|}{ Females } \\
\hline & $\begin{array}{c}\text { Controls } \\
n=\varepsilon 1\end{array}$ & $\begin{array}{c}\text { Patients } \\
n=0 .\end{array}$ & $\begin{array}{l}\text { controls } \\
n=r_{0}\end{array}$ & $\begin{array}{c}\text { Patients } \\
n=r r\end{array}$ \\
\hline $\begin{array}{l}\text { Mean corpuscular } \\
\text { volume }(\mathrm{MCV}) \\
\left(1 \cdot \cdot^{-10} \mathrm{~L}\right)\end{array}$ & $19 . Y_{0} \pm 0.0$ & $৭ \cdot . \wedge \pm 1 \cdot . \wedge$ & $19,7 \cdot \pm 0.9$ & $\wedge \wedge . \Upsilon_{ \pm} \Upsilon_{\text {r. }} \varepsilon$ \\
\hline $\begin{array}{c}\text { Mean corpuscular } \\
\mathrm{Hb}(\mathrm{MCH}) \\
(\mathrm{pg})\end{array}$ & $r \wedge . Y \backslash \pm r . \cdot T$ & $r q . r V_{ \pm} r . \wedge$ & $r \Lambda_{.} \cdot \Lambda_{ \pm} r .70$ & $r V . Y I \pm \varepsilon . r_{O}$ \\
\hline $\begin{array}{c}\text { Mean corpuscular } \mathrm{Hb} \\
\text { concentration } \\
(\mathrm{MCHC}) \\
(\mathrm{g} / \mathrm{L}) \\
\end{array}$ & 119.117 .0 & 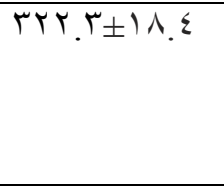 & $r \backslash, r \pm l Y . r$ & $r .0 . r \pm 1 \tau . r$ \\
\hline $\begin{array}{c}\text { Red cell distribution } \\
\text { width }(\mathrm{RDW}) \\
\left(1 \cdot{ }^{-10} \mathrm{~L}\right)\end{array}$ & $9.9 \pm 1.01$ & $\wedge . \vee \Delta_{ \pm 1} . \wedge r$ & $9.19 \pm 1 . r v$ & $9.1 r \pm r .01$ \\
\hline $\begin{array}{c}\text { Hemoglobin } \mathrm{Hb} \\
(\mathrm{g} / \mathrm{L})\end{array}$ & $1 \varepsilon \cdot \pm 1 \cdot .7$ & $1 \Gamma ! . V_{ \pm} / r_{*}$ & $\left|r \varepsilon . r_{ \pm}\right| q . \wedge$ & $\left\|V_{ \pm}\right\| Y_{.} V^{*}$ \\
\hline $\begin{array}{c}\text { RBCs count } \\
1.1 \% / L\end{array}$ & $\varepsilon . \wedge I \pm \cdot . r q$ & $\varepsilon .0 \Gamma_{ \pm} \cdot . \leqslant 1$ & $\varepsilon . r^{\prime} \pm \cdot r_{0}$ & $\varepsilon . r_{ \pm} \cdot r_{0}$ \\
\hline $\begin{array}{l}\text { Hematocrit } \\
(\%)\end{array}$ & $\varepsilon r . V Y \pm r . V Y$ & $\varepsilon 1 . \cdot T \pm r . T \varepsilon$ & $r q . r q \pm r .1 V$ & $r \wedge .19 \pm r .11$ \\
\hline $\begin{array}{c}\text { WBCs count } \\
(1 \cdot r / \mathrm{mL})\end{array}$ & $V .7 \pm 1.7 V$ & $v . r q \pm r .1 \leq$ & $V . Y \leqslant \pm 1.0 \leqslant$ & $V . \Delta V_{ \pm} Y . Y \wedge$ \\
\hline $\begin{array}{l}\text { Platelet count } \\
(1 \cdot 9 / \mathrm{L})\end{array}$ & $r \wedge \cdot \pm 0 \cdot V$ & $r 00 \pm V \cdot .1$ & $r \circ q_{ \pm} r \leqslant .0$ & $r \neg \varepsilon \pm \lambda \varepsilon . Y$ \\
\hline
\end{tabular}

WBCs and platelet counts did not significantly decline in patients group as compared to control group. Evans et al. ${ }^{9}$ and Halikas et al. ${ }^{1}$ did not notice any significant changes in WBCs and platelet counts. Therefore, frequent blood testing is not necessary in asymptomatic patients'. On the other hand, WBCs and RBCs counts decreased after $r$ months of carbamazepine therapy and remained at lower level for ${ }^{\circ}$ years'.

Rare but serious aplastic anemia was reported in patients treated with carbamazepine." "' The rapid onset of aplastic anemia and thrombocytopenia occurred by carbamazepine, while leucopenia developed more slowly within $r$ months, therefore; daily laboratory checks in the first few months of carbamazepine therapy 
would be necessary to monitor these serious hematological reactions. ${ }^{\mathrm{V}}$ These serious hematological reactions were not observed in the studied patients, since the measurements were done for those patients with chronic use of carbamazepine.

In conclusion, carbamazepine decreased HB but not the other full blood count. Chronic use of carbamazepine is relatively safe. Periodical examination of carbamazepine patients for full blood count is necessary.

\section{Acknowledgments}

The study was supported by the Mosul College of Medicine, University of Mosul, Iraq.

\section{References}

1. McNamara JO. Pharmacotherapy of epilepsies. In Brunton LL, Lazo JS, Parker KL eds. Goodman . Gilman's The pharmacological basis of therapeutics, $11^{\text {th }}$ edition. New York: McGraw-Hill, Y..V:0.1_0Y T.

r. Mauricio T, Jose C, Ross JB, Carlos Jr Z, et al. Blood dyscrasias with carbamazepine and valproate: A pharmacoloepidemiological study of $Y, Y Y \wedge$ patients at risk. Am J Psychiatry 1990;10r: \&1r_A.

$r$. Harden CL. Therapeutic safety monitoring: What to look for and when to look for it. Epilepsia $r \ldots ; \leqslant)(\operatorname{supp} \wedge): S^{\top} \vee-S \leqslant \varepsilon$.

$\varepsilon$. Ishikita T, Ishiguro A, Fujisawa K, Tsukimoto I, et al. Carbamazepineinduced thrombocytopenia defined by a challenge test. Am J Hematol 1999;7r:Or_o.

๑. Tutor-Crespo MJ, Hermida J, Tutor JC. Relation of blood platelet count during carbamazepine and oxacarbazepine treatment with daily dose and serum concentrations of carbamazepine, carbamazepine-1.,11-epoxide, and 1.-hydroxycarbazepine. Biomed Pap Med Fac Univ Palacky Olommouc Czech Repub Y..V; 101:91-ร.

7. Pellock JM. Carbamazepine side effects in children and adults. Epilepsia $19 \wedge \vee ; \curlyvee \wedge: S \neg \leqslant-\vee \cdot$.

$\checkmark$. Betticher DC, Wolfisberg HP, Krapf R. Aplastic anemia in carbamazepine therapy. Schweiz Med wochenschr 1991; 1 1):0^r_A.

^. Oyesanmi O, Kunkel EJS, Monti DA, Field HL. Hematologic side effects of psychotropics. Psychosomatics $1999 ; \varepsilon \cdot: \leqslant 1 \leqslant-r)$.

१. Evans OB, Gay H, Swisher A, Parks B. Hematologic monitoring in children with epilepsy treated with carbamazepine. J child neurol

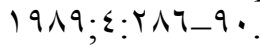

$1 \cdot$ Hemingway C, Leary M, Riordan $\mathrm{G}$, Walker K. The effect of carbamazepine and sodium valproate on the blood and serum values of children from a thirdworld environment. J child neurol 1999;1 ₹:V01 - r.

11. Shah A, Jamil AA, Gupta VP,Kabitaj MM, et al. Antiepileptic drugs and anemia: A prospective study in epileptic children. JST $r \ldots r ; r: r \vee r r \varepsilon$.

Ir. Tagawa T, Sumi K, Uno R, Itagaki $\mathrm{Y}$, et al. Pure red cell aplasia during carbamazepine monotherapy .Brain Dev 199v;19:r..r.

1r. Shah QA, Jamil AA, Gupta VP, Kabiraj MM, et al. Anti-epileptic drugs(AEDs) and body electrolytes in childhood epilepsy: a prospective study. JST $r \cdots r ; r: \leqslant r_{-}$ o.

I ร. Halikas JA, Nugent S, pearson VL, Crosby RD, et al. The effect of carbamazepine on white blood cell count in cocaine busers. Psychopharmacol bull 199r;rq:r人r_ᄉ. 
10. Isojarvi J, Pakarinen AJ, Myllyla VV. Basic hematological parameters, serum gammaglutamyl-transferase activity and erythrocyte folate and serum vitamin Blr levels during carbamazepine and oxacarbazepine therapy. Seizure 199v; $: r \cdot v-11$.

17. Blackburn SC, Oliart AD, Garcia Rodriquez L, Perez Gutthann S.
Antiepileptics and blood dyscrasias: Pharmacotherapy 1991; 1N:1 rVV_ Nr.

IV. Sobotka JL, Alexander B, Cook BL. A review of carbamazepine hematologic reactions and monitoring recommendations. DICP $199 \cdot ; r \leqslant:|r| \leqslant-9$. 